\title{
5 \\ Land tenure and identity in the New Zealand high country
}

\author{
Carolyn Morris
}

\begin{abstract}
People and places are mutually constitutive, and so the particular ways in which people attach and are attached to place have implications for both. A significant aspect of attachment is mode of tenure, with different forms of land tenure allowing for very different imaginaries and practices of self and land. As such, transformations in tenure will have significant implications for land use and subjectivity.

Until recently, farmers leased 2.37 million hectares of pastoral land in the South Island from the Crown and, since 1948, leaseholders have had the right of perpetual renewal. In the mid 1990s, the Crown (with the broad support of farmers, environmental and recreation interests) moved to reorder its relationship with farmers and a process of tenure review was initiated. As a result of tenure review, land with significant conservation and landscape values is being transferred to the Department of Conservation, in return for which farmers are gaining freehold title of lower land, land with production potential. For the people of the high country, relationships to the land are central to the formation of subjectivity, and it is the highest and most remote land, the very land that farmers stand to lose under tenure review, that has the greatest significance for identity. As one informant said, 'Tenure review means that we would become valley farmers', no longer high country farmers. With tenure review in process, the matrix that produces high country farmer identity has been disrupted. As such, it provides a moment in which the simultaneous processes of production of person and place are revealed as differently positioned actors struggle to control the future of the high country.
\end{abstract}

\section{Introduction}

In many of the so-called developed countries, rural places and conceptions of ruralism appear to be undergoing radical transformation. Historically, in Anglo traditions, high moral value has been attributed to ruralism, and notions of the rural idyll have deep histories (Williams 1973; Schama 1995), an enduring aspect of which is the idea that rural regions are sites for the production of national 
goods - economic and cultural. In these traditions, ruralism and agrarianism have been often considered synonymous (suppressing the brute realities of agricultural life), but in recent decades this link has begun to be uncoupled. In many European countries, in America and in Australia, the number of people involved in farming has declined and rural production forms an ever-smaller part of national economies. The decline in the economic importance of rural areas, however, has not necessarily resulted in a concurrent diminishment of cultural significance. Instead, the notion of the rural idyll has been reconfigured, in this iteration divorced from agricultural production: rural areas are more and more becoming sites and objects of consumption (for example, Ching and Creed 1997).

The effects of these broad transformations are significant. Transformations of ruralism are simultaneously transformations of landscape, of lived lives in place, of imaginaries and of subjectivities. What we see, as the idea of ruralism is reworked, is a transformation of the place of ruralism in imaginings of place, community, the nation and the self. Though the general trajectory of change might be common across nations, as anthropological approaches to globalisation commonly demonstrate, such processes manifest differently in different places and the outcome of any trajectory of change is always contingent (for example, Inda and Rosaldo 2002). As such, to understand rural change it is necessary to explore particular types of ruralism. As Bourdieu (1998:2) writes, 'the deepest logic of the social world can be grasped only if one plunges into the particularity of an empirical reality, historically located and dated'.

New Zealand presents an unusual case of rural change. In New Zealand, as in other developed nations with strong Anglo heritages, ruralism has loomed large in the national imagination and is understood as the fount of the country's identity, the reservoir of national morality (Bell 1996). On the other hand, though allegedly a developed country, New Zealand's economy is unusual in its continued reliance on primary production: 'agricultural and forestry products earn more than half of New Zealand's export income' and 'farming and forestry employed about 8.5 percent of employed people aged over 15 years in 2001' (Statistics New Zealand 2002). Despite this, however, and in contrast with policies of subsidising agricultural production and supporting farmers regardless of their waning economic significance in other developed nations, since the mid 1980s and the implementation of wide-ranging neo-liberal reforms, the agricultural sector in New Zealand has received no government support or subsidy whatsoever (Sandrey and Reynolds 1990; Gouin et al. 1994). Notwithstanding the centrality of primary production to the economy, in New Zealand as elsewhere, we see a process whereby consumption values have come to trump production values in relation to ruralism, and the 'natural' link between agrarianism and rurality is being severed. 
Just as there are significant differences between nations with regard to the place of ruralism, so there are differences within nations. Recent decades have seen profound alterations in the agricultural sector in New Zealand: 'with fewer sheep, more dairy cows, more trees, burgeoning vineyards and spreading avocado orchards and olive groves' (Statistics New Zealand 2002), New Zealand no longer lives on the sheep's back. Between 1994 and 2002, there was a 20 per cent decline in sheep numbers to 39.5 million and an increase in dairy cow numbers, from 3.9 million to 5.2 million. There were dramatic increases in grape plantings in the same period, rising from 7200 hectares in 1994 to 17400 ha in 2002 (Statistics New Zealand 2002). These changes have radically reordered life in particular localities, with profound impacts on ruralism as symbol, landscape and community, and on possible rural futures. This chapter considers one particular case of rural change in New Zealand: pastoral sheep farming in the South Island high country. Because of the symbolic stature of the high country, this case also speaks to the place of ruralism in New Zealand's imagining of itself as a nation. As such, I simultaneously address rural futures and the future of ruralism.

Cohen (1985) argues that when communities perceive themselves to be under threat, they mobilise to assert their distinction from others, drawing from a collective repertoire of discourses and symbols to articulate who they are in order to achieve certain ends. The situation I will describe is just such a case. It is very much in flux, with outcomes uncertain. As such, this analysis attempts to capture a particular moment in what is a continuing process. In such instances of disruption to the previously taken for granted order of things, the effects and processes of rural change become visible, as social actors struggle to secure their land, their communities and their selves.

\section{Place and subjectivity}

The link between place and subjectivity has been established theoretically and empirically by a number of authors (for example, Altman and Low 1992; Hirsch and O'Hanlon 1995; Feld and Basso 1996; Low and Lawrence-Zúñiga 2003), and in relation to farming has been explored in most detail by Gray $(2000,2003)$ in Scotland and Dominy $(1992,1993,2001)$ in the New Zealand high country. The ethnographies of Dominy and Gray focus on the ways in which farmers come to selfhood through an experiential and embodied knowledge of the land they farm. There has, however, been less attention paid to other aspects of the formation of farmer subjectivity. Things such as policy and regulation, legal structures and politics tend to be constituted as context, as shaping what farmers might do, but essentially as external to their selves. In this chapter, I focus on land tenure. Rather than thinking of tenure as an element of context, however, I will argue that tenure is in fact one of the building blocks of farmer subjectivity. As McNay (2000:76) writes, 'individuals do not passively absorb external determinations, but are actively engaged in the interpretation of experience, 
and therefore, in a process of self-formation'. Different forms of tenure attach people to land in different ways, providing different understandings of the relationship between land and people and producing different forms of being in those worlds. As such, changes in mode of tenure will necessarily result in alterations in identity. I explore the ways in which the legal matrix of land tenure is productive of high country farmer identity. Currently, land tenure in the high country is changing from leasehold to freehold. With tenure review, a previous identity, grounded in place and legitimated through a particular relationship with the Crown, is under threat (or is at least being destabilised), as one of the key modes through which that identity has been authenticated is being removed. Changing land tenure, in reordering the connection between farmers and the State, is producing a new form of farmer subjectivity, and an oppositional subjectivity. Farmers are reimagining themselves in relation to the State and to the nation. In turn, this change in tenure is part of a transformation of the place of high country farmers in the polity and the nation.

\section{High country pastoral farming}

The high country is land above 600 metres in altitude that runs the length of the South Island. High country farming is characterised by the extensive grazing of merino sheep on large properties, ranging from approximately 2500ha to 180 000ha, with wool as the major commodity. The high country is a vast area: 6 million of the 27 million hectares of New Zealand's land mass is high country land. About 2.5 million hectares is farmed; the rest is part of the conservation estate (<http://www.highcountryaccord.co.nz/>). Pastoral land, then, constitutes almost 10 per cent of the land of New Zealand. Very little of this land is held under freehold title. Until the late 1990s, 2.37 million hectares were held in Crown ownership, let to 304 farmers as Crown Pastoral Lease. The Land Act 1948 created leases that were perpetually renewable for a term of 33 years, though there was no right to freehold. Rents were set at between 1.5 and 2 per cent of land value exclusive of improvements. The lessee had many of the same rights as freeholders: trespass rights, rights of exclusive occupation and the ownership of improvements. These leases were, however, pastoral leases only, meaning that leaseholders had only the right to graze the land and had to apply to the Crown agency responsible if they wished to undertake any other activities. This provision of the act thus ensured that the extensive grazing of sheep and cattle remained the dominant land use in the high country. The security of tenure granted by the 1948 act promoted the investment of money, time and self in high country properties and a strong sense of belonging to the high country developed in run-holders. From the perspective of high country farmers themselves, and for writers such as Dominy (2001), a unique high country 'culture' emerged, based on the practices of farming that land. As one high country farmwoman put it: 'We're only second generation, but we still have a 
firm cultural attachment to the land. We have cultural, spiritual and historical connections' (Karen Simpson, The Christchurch Press, 22 November 2003).

The 1948 act made possible a particular mode of attachment to the high country. As the land remained in Crown ownership, a relationship of stewardship was available - the idea of the leaseholder as guardian and caretaker of the land. As one farmer said: 'We're custodians. Nobody ever owns it, we're just passing through and trying to enhance it for the next generation' (Andrew Simpson, The Christchurch Press, 22 November 2003). This imagining of the relationship between farmer and land differs from that of other farmers, because the land is leased. And it was, in part, through the 1948 act that the potential for stewardship subjectivity, rather than ownership subjectivity, was generated.

Expressions of belonging and attachment to place are mobilised by particular groups at particular times for particular reasons. At the Ngai Tahu Claim hearings before the Waitangi Tribunal in the late 1980s, ${ }^{1}$ anthropologist Michele Dominy (1990:13-14), presenting evidence of run-holder attachment to place, stated: 'Material affinity is expressed in the value runholders place on their sense of ownership in the land they farm and inhabit. It is also expressed in the value placed on long term security of tenure.' In this context, when control of the leases was at stake, a discourse of ownership rather than stewardship was deployed. Current assertions of attachment must, then, be viewed in the same light: as strategic deployments by interested actors.

\section{The tenure review process}

In the mid 1990s, the Crown instituted a process of tenure review, considering that the system of pastoral leases had outlasted its usefulness as a means of protecting land and promoting agricultural development (Clayton 1982:65). Tenure review aimed to 'achieve...productive economic land-use and conservation outcomes in the South Island high country' (<http://www.linz.govt.nz/home/index.html $>$ ). Tenure review was widely supported by farmers, recreation and environmental groups (Brower 2006:27). Farmers and environmentalists had different reasons for wanting tenure review, but there was general agreement that it was required:

High country lessees wanted to have the management and investment flexibility that comes from freehold title. The Crown wanted to get out of the uneconomic business of being a landlord. And the Environmental pressure groups, along with the Crown, wanted land with significant inherent values (SIVs) to go into the conservation estate. (<http://www.highcountryaccord.co.nz/>)

Under the terms of the 1998 Crown Pastoral Lands Act, leaseholders have the opportunity to convert to freehold part of their land - that considered to have economic values - in return for which land with significant historic, scientific, 
ecological or cultural characteristics is restored to full Crown ownership, and, in reality, to Department of Conservation (DoC) management (<http://www.linz.govt.nz/home/index.html $>$ ).

Tenure review is initiated by individual leaseholders and, through consultation with the Department of Conservation, Fish and Game, ${ }^{2} i w i^{3}$ and the general public, individual properties are divided into freehold and conservation land. Tenure review is a voluntary process and leaseholders or the Crown can withdraw at any time (<http://www.linz.govt.nz/home/index.html $>$ ). The results of tenure review will vary by property. In some cases, all of the land of a particular lease might go to conservation and, in others, all of the land might be converted to freehold (<http://www.linz.govt.nz/home/index.html $>$ ). As of August 2007, 47 lessees had settled with the Crown, with another 13 in the final stages, and 115 properties had not entered the process (<http://www.linz.govt.nz/ home/index.html >). To date, about 162000 ha of land have been converted to freehold and about 117 500ha have been added to the conservation estate, with an additional 45 500ha being bought outright from lessees $(<$ http://www.highcountryaccord.co.nz/>). Officials estimate that, by the end of the tenure review program, 50 per cent of pastoral lease land will become freehold and 50 per cent will become conservation land $(<$ http://www.linz.govt.nz/home/index.html $>$ ). To date, the split has been closer to 60/40 in favour of farmers (Brower 2006:3).

At present, tenure review seems to be stalling. Farming, conservation and recreation groups have begun to voice serious doubts about the outcomes of tenure review and are lobbying hard to change the outcome. Tenure review has become contentious because what is at stake is not just ownership of land, or even conservation, but control over the way in which the high country and New Zealand as a nation is imagined. Two web sites, produced by farmer lobby group High Country Accord (<http://www.highcountryaccord.co.nz/ $>$ ) and conservation/recreation lobby group Stop Tenure Review $(<\mathrm{http}: / /$ www.stoptenurereview.co.nz/>), give insight into how the different groups understand the issues and the discourses they deploy to make their respective cases.

\section{The high country and New Zealand identity}

Ruralities and nature are central elements in New Zealand's imagining of itself as a nation (for example, Bell 1996; Sturm 1998; King 1999; Dominy 2001:68; Jutel 2004) and in the construction of the New Zealand national subject. Despite a very high degree of urbanisation (85.7 per cent of the population was classified as urban, according to the 2002 census), ${ }^{4}$ a '[n]ational identity based on physical geography, and on idealisation of lifestyles within nature, is persistently used as our claim to fame' (Bell 1996:34). According to Jutel (2004:54-5), three landscapes have particular significance: 'dramatic volcanic topography, the 
pastoral farmland, and the exotic "otherness" of the native bush are located at the centre of New Zealand national identity constructs'. These landscapes are iconic and stand for the nation. Such imaginings are widely disseminated and have continuing salience. For example, White (2006), writing in North and South, a monthly magazine for, in the words of the magazine's web site, 'thinking New Zealand', wrote of the high country:

The empty inner expanse has been the backdrop of pioneer legend and in inspiration to everyone from Samuel Butler, to Brian Turner, Grahame Sydney to Speight's marketers. Autumn musters; the desiccated Otago tors; the Mackenzie Country's tawny tussock carpet; the remote corrugated iron huts with names of sheltering shepherds scratched in their rafters; the 'red-gold cirrus/Over snow mountain shine' of James $\mathrm{K}$. Baxter are part of a cultural heritage we all share and celebrate, no matter how deep in suburbia we dwell. (White 2006:42)

Not only does the land of the high country carry immense symbolic weight, so does (or perhaps so has) the high country farmer, because of his intimate connection with the high country landscape. In the popular (and farmer) imagination, this iconic land has forged an iconic subject, a subject who embodies all that is best in the national character. The high country farmer subject position is constituted through discourses of pioneering. As McAloon (2002:109) noted, the pioneer subject position was established from the early days of the colony: as early as 1890, 'the pioneer myth... was becoming increasingly evident in the account rich settlers gave of themselves'. High country farmers continue to constitute themselves through this discourse: 'in many respects the "high country farmer" is an image of yesteryear, a portrayal of the early settler battling against the elements to earn a living' (Cushen 1997:78). Pioneering people are hardworking, thrifty, resilient, flexible, independent and self-reliant; they are possessed of what Wevers (1980:244) calls the stoic virtues. These are the characteristics of the New Zealand national subject, embodied in national heroes such as the late Sir Edmund Hillary (conqueror of Mount Everest), Charles Upham and Bill Apiata (winners of the Victoria Cross) and countless All Blacks captains. Likewise, they are possessed by the high country farmer. Moreover, high country farmers have played a significant role in building the nation's wealth (Gardner 1981; Bremer and Brooking 1993).

It is because of the place of the pioneering high country farmer in the foundation myths of the nation, the iconic stature of the land they farm and their economic contribution that high country farmers have become established as central to New Zealand's national identity and as guardians of the nation's physical and cultural heritage. Farmers considered that their interests paralleled the nation's interests because of the natural moral superiority of ruralism and because they produced the wealth of the nation: '[m]ost other groups seemed parasitic in 
comparison with family farmers who constituted the "backbone of the economy"" (Bremer and Brooking 1993:108). This status translated into a dominant cultural and political position in the affairs of the State, with successive governments supporting agriculture: '[t]he history of New Zealand farming is in a real sense the history of New Zealand. Until the Second World War all life here was powerfully conditioned by what happened in the country' (McLauchlan 1981:11). Also, until the 1980s, '[s]tate economic policies exhibited a clear bias in favour of the farming community' (Bremer and Brooking 1993:108). Considerable rewards accrued to farmers as a result. Brooking argues that 'the image fostered of the pastoralist as a "natural" part of a romantic high country, as the guardian of a way of life, has helped legitimise their claim to control huge tracts of land leased from the state at peppercorn rentals' (Brooking in Cushen 1997:74-5).

The place of high country farming and farmers in the national imaginary, however, is being transformed. What I suggest is happening through tenure review is that farmers are being dislodged from their position of national subject and are being replaced by the environmentalist (understood as urban greenie), and an unspoiled nature is replacing a productive ruralism as the morally correct relationship to the high country.

\section{High country farmer identity}

High country farmer subjectivity is, as all research and all of the writings by high country farmers themselves indicate, inextricably bound up with the land. Dominy's work demonstrates in most detail the 'mutuality of spatiality and cultural identity' in the high country, how land is a site of 'intense cultural activity and imagination - of memory, of affectivity, of work, of sociality, of identity' (Dominy 2001:3). Not all of the land, however, on a high country station carries the same symbolic weight. It is the land that is the highest, the most remote - the tops, the back country - that bears the greatest symbolic load. It is the possession of this land that forms the foundation of high country farmer subjectivity, and farmers are aware that its loss will necessarily transform identity.

In interviews conducted in 2003 about the impact of tenure review (Akers 2004; Morris and Akers 2004), interviewees expressed concern about what tenure review would mean for the future of the high country. High country people articulated a deep sense of attachment to high country farming as a way of life, as in the words of one young woman: '[I]t's just everything to me. It's just absolutely everything, it's my whole life. It's more important than boys, school [university] and everything' (see also Dominy 2001; Morris 2002). Whether they had entered the process or not, and whether they considered that they would personally do well out of tenure review, farmers expressed deep concern about the impact of changing land tenure on being in the high country. They were concerned that there was a desire for the removal of farmers from the high 
country altogether: 'We're the thorn in their side, the greenies. They want home [the station]...they would love to get their hands on everything' (Morris and Akers 2004). This, farmers say, would result in the destruction of the high country, physically and culturally:

In the worst case scenario the high country will still be there but the high country will transform because the vegetation type, the land use type, it'll revert back to where it came from. The local, indigenous ${ }^{5}$ people will disappear because it will become uneconomic to live in these environments, so they'll disappear. (Morris and Akers 2004)

Though it is unlikely that farming will disappear entirely from the high country, with the transfer of the highest country from farmer to DoC control, high country farming could do so. True high country farming requires particular kinds of country (extensive, rugged, isolated, high-altitude tussocks with snow risk; Dominy 2001:42), and the loss of such land will mean that particular properties might no longer qualify. In response to a question about what tenure review would mean for their property, one farmer responded:

Yeah, it's still high country, it's still a high country place. A lot of places aren't probably. We still will be 'cause we'll still have some high bits of land, real tussock, you know, real rugged stuff. But a lot of places won't be, I suppose, when they [DoC] cut what they want out. (Morris and Akers 2004)

This farmer will remain a high country farmer because he will retain real high country land, but is not likely to be the case for everybody. For those who lose the highest country, the high country farmer subject position will no longer be available. In the words of one woman: 'We are an endangered species.' High country farmers will become instead 'valley farmers', sheep farmers like any others, no longer unique.

Significantly, it is the possession of the very same land that is the goal of environmental and recreation groups. The high country is central to their identity projects as well, projects they increasingly successfully constitute as New Zealand's project, just as farmers, until recently, have been able to do.

\section{Recreation and environmental interests in the high country}

People who do not live in the high country consider that they have rights in relation to it because of its iconic nature and because it remains in Crown, and therefore in some sense public, ownership. Farmers are not the only group interested in the outcome of tenure review. As the process evolved and a number of reviews were completed, environmental and recreation interests became increasingly vocal in their criticism, resulting in the formation of a lobby group called Stop Tenure Review. 
From the perspective of this group, and others such as Forest and Bird, tenure review will result in the privatisation of the high country, with negative implications for conservation, recreation and landscape. They argue that too much land is being converted to freehold, land with significant natural and recreation values that should be included in the conservation estate, and that farmers are benefiting from tenure review at the expense of the New Zealand public. Eugenie Sage of Forest and Bird, for example, says the high country is being given away in 'the biggest wave of privatisation... since Roger Douglas'. She says she fears that iconic landscapes will pass into private hands to become 'McMansion subdivision sprawls' (<http://www.highcountryaccord.co.nz/>). These groups note that under tenure review farmers give up their least productive land and in return receive land of much greater value, and in some cases cash settlements as well: 'So far high country farmers have received agricultural and real estate development rights worth tens of millions of dollars from the Crown AND an average of $\$ 186,000$ extra compensation per deal' (<http://www.stoptenurereview.co.nz/>). Like the farmers, Stop Tenure Review argues that what is being lost is not just land, but 'identity':

Ever since European settlement, 150 years ago, the South Island high country has been owned by the Crown. But we are not concerned just about land ownership. It's also about protecting a spiritual landscape and an environment that is an indelible part of our collective heritage. It's more than just our land, it's part of who we are as New Zealanders. So while the government is handing over Crown land and taxpayers' money to a small group of high country farmers, it is also alienating our identity. (<http://www.stoptenurereview.co.nz/>)

These groups draw attention in particular to the privatisation of lakefront land: under the Mt Burke review, 35km of Wanaka shore was converted to freehold and $9 \mathrm{~km}$ of Lake Tekapo frontage was converted to freehold under the Richmond review (<http://www.stoptenurereview.co.nz/>). The group cited cases in which land converted to freehold under tenure review was subsequently subdivided and sold by farmers for massive profits. For example, the Closeburn lessee paid $\$ 158000$ for 930ha of land on the shores of Lake Wakatipu, close to the tourist hub of Queenstown; in 2006, a 1.2ha section of Closeburn Station land was on the market for \$3.9 million (White 2006:46-7). In 2006, Fulbright Scholar Anne Brower published the results of her research into tenure review in a report called Interest Groups, Vested Interests, and the Myth of Apolitical Administration: The politics of land tenure reform on the South Island of New Zealand. In this report, Brower argues that the Crown is being exploited by farmers who are making massive financial gains at the expense of the Crown and the New Zealand public.

This report, and the furious response from farmers, brought tenure review to the public's attention. In November 2006, the magazine North and South 
published an article titled 'High country hijack'. This article leads with the Brower and environmentalist perspective and suggests a conspiracy:

It's a process whereby 10 percent of New Zealand's most remote but most beautiful country, owned by the Crown, is being divided up, with much of it effectively given away to farmers, who until now have only leased this land. It's called tenure review and it's been going on for 15 years but it's only now people seem to be understanding what's really happening, how many iconic landscapes are under threat - and what's already been lost. Warning. This is a complex story. It's been made complex - or nobody involved with it has tried to make it simple - perhaps so that people like you won't become interested in it, let alone get involved. (White 2006:42)

\section{Farmers' perspectives}

It is not only environmental groups who are unhappy with the outcomes of tenure review; so, increasingly, are farmers. In 2003, a high country lobby group called the High Country Accord was established, aiming 'to seek a change in government policy relating to the Land Tenure Reform Process' (<http://www.highcountryaccord.co.nz/>).

In opposition to Stop Tenure Review, the High Country Accord denies claims that farmers are the beneficiaries of tenure review:

Forest and Bird has been creating a perception that the public is somehow being ripped off. There is a clear implication that individual farming families are somehow guilty parties. It has all become very unfair and unpleasant... By ignoring [the] facts and playing to an old prejudice that high country farmers are unfairly privileged people, Forest and Bird have finally managed to attract the urban media to take an interest in what has been happening in the high country.

(<http://www.highcountryaccord.co.nz/>)

Rather, they argue, it is farmers who are doing badly. From the perspective of the High Country Accord, tenure review is unsatisfactory because too much land will be lost from production. Farmers argue that much of the land that is earmarked for conservation is necessary for the viability of stations and high country community life:

Most of this land is suitable for long-term sustainable economic use. But it is going to be locked away in [the] conservation estate forever. As high country farmers we are particularly concerned, because we will lose most of the tussock rangeland which we need for summer grazing. Without access to this land, most high country farms will not be viable...The creation of government-owned parks and reserves should 
not be at the expense of the families who farm this land sustainably. (<http://www.highcountryaccord.co.nz/>)

Indeed, the impact on the merino industry is likely to be significant. A report by Lincoln agricultural economist Glenn Greer estimates that tenure review will result in the 'loss of 663,000 stock units from the high country - a 31\% reduction on current numbers. The estimated loss of gross economic output at the farm gate per year will be $\$ 33$ million' (<http://www.highcountryaccord.co.nz/>). The accord estimates that one in five properties will become economically unviable, with the loss of 70 to 80 families from high country farming (<http://www.highcountryaccord.co.nz/ $>$ ). The accord argues that this will destroy farming as a way of life and, in doing so, will destroy New Zealand's heritage:

In seeking to nationalise 60 per cent or more of pastoral lease land, the Crown has failed to recognise the value to the nation of the productive effort and commitment to these lands by existing farming families for over 150 years...we are a self-reliant community in which concern for the safety of neighbours and visitors is part of the culture... We live in this landscape 24 hours, 7 days a week and we understand the risks and how to manage them. It's a very different culture from that which the government would have us replaced with - that of the transitory visitor, supported by a seasonal and possibly itinerant workforce. As high country farmers we are managers of the landscape and part of it. We are part of a living heritage which most New Zealanders and tourists value. (<http://www.highcountryaccord.co.nz/>)

Although, as in this statement, farmers position themselves as the rightful guardians of the high country, a delicate discursive strategy is needed here, because it is the deployment of the discourse of guardianship rather than ownership that is one of the things that has allowed other New Zealanders to mount compelling claims to participate in decision making about the future of the high country. As a result, the High Country Accord has begun to argue that leasehold tenure almost amounts to freehold:

[L]eases give farmers exclusive occupancy rights to their property, as well as a perpetual right of renewal. In these respects, the leases have a status which is very similar to freehold title...The lessee's financial interest in a typical High Country farm is 85 per cent of the capital value. The Crown's interest is the remaining 15 per cent...we are not talking about rental agreements for state houses.

(<http://www.highcountryaccord.co.nz/>) 
The High Country Accord argues that farming and conservation are not incompatible. Indeed, they suggest, farmers are better able than the State to be environmental managers:

$[\mathrm{M}]$ ost of the land being targeted by the Crown could be protected while still remaining in private hands. There is no evidence to show that the Crown is a better land manager than farmers. In fact, there are many examples of land in Crown ownership which is poorly managed. Scientific research shows that most tussock rangeland is being sustainably managed by farmers. The fact that the land still has conservation values after 150 years of grazing is a testimony to their stewardship.

(<http://www.highcountryaccord.co.nz/>)

In arguing their case, the accord positions farmers in opposition to the State but as having parallel interests with the New Zealand public (that is, the nation): 'Accord members are privileged to farm some of New Zealand's most magnificent landscapes. We accept that our fellow New Zealanders want the right to enjoy these landscapes too' (<http://www.highcountryaccord.co.nz/>). What they object to is the extent of the proposed conservation estate, which they constitute as the aim of the government, not, by implication, the aim of the public:

Our objection is to the scale of the government's plans. Basically, we think the government is going overboard. Instead of establishing a handful of parks in key areas, it plans to set up 22. About 1.3 million hectares will be involved. That's a huge area-it's more than Fiordland National Park. (<http://www.highcountryaccord.co.nz/>)

Again, they position themselves and their interests with the public and against the government:

Ultimately New Zealanders need to ask whether they want more than half the land area of the South Island locked into Crown ownership and management indefinitely. The techniques used by the government to acquire this land amount to an abuse of property rights. Every New Zealander who owns land, shares or other investments should be concerned that such a precedent is being set.

(<http://www.highcountryaccord.co.nz/>)

The accord suspects that the ultimate aim of the Crown is to remove farmers from the land in the name of the retention of a 'natural' landscape, which farmers assert is in fact produced (and sustained) through their farming practices.

\section{Farmers, the State and subjectivity}

Two kinds of transformations in farmer subjectivity are being produced through tenure review. First, a steward subjectivity - in which the interests of the State and farmers coincide, and through which farmers are positioned as guardians 
of the nation - is no longer easily sustainable. Farmers attempt to deploy this discourse at times, but it has lost the power it once had. Second, as farmers find themselves in opposition to the policies of the State, a resistant subjectivity is produced. This represents a radical change from times when farmers were considered to be the economic and symbolic backbone of the nation. Farmers and farming are no longer understood in this way. Increasingly, they are regarded as an ecological threat to the nation (their gas-emitting cows are contributing to global warming, fertiliser run-off is polluting rivers and lakes and so on) or as simply businessmen, motivated purely by profits, with discourses about farming as a morally superior way of life increasingly ringing untrue.

The unravelling of the close relationship between farmers, the State and the nation has its roots in the 1980s and the neo-liberal policies of the fourth Labour Government. In the 1980s, in a very short time, all supports for farming were removed and the sector was deregulated, exposing New Zealand agriculture to the full brunt of market forces (Sandrey and Reynolds 1990; Johnsen 2003). This resulted in profound crisis for farmers - economic and symbolic. If the historical extent of government support for agriculture signalled farmer's iconic status, the removal of that support signalled its loss. Farmer power was further undermined with the 1996 electoral system change to MMP, a system of proportional representation. Under the new system, smaller parties have a greater voice, and one of the new parties in Parliament is the Green Party. Greenies are the traditional enemy of farmers, representing interference from outside and the imposition of alien values. Farmers are concerned that the power of such interests (constituted as urban) will increase (Cushen 1997:5). And, it seems, their worries have some foundation. In June 2007, David Parker, the minister responsible for tenure review, announced the withdrawal of the Crown from some 40 tenure reviews to, in his words, 'protect important high country landscapes and diversity values' ('High country tenure review decision welcomed', Scoop Independent News, 22 June 2007). These properties are those with lakeside frontages - precisely the kind of land that farmers have the most to gain from converting to freehold. This effectively means that this land will remain in Crown ownership, though whether it will continue to be farmed or become conservation estate is not clear. Stop Tenure Review welcomed the decision, farmers deplored it: '[o]ptions for High Country farmers are becoming increasingly limited by a government which seems determined to force them from their leasehold land', said Donald Aubrey, chair of the High Country group of Federated Farmers ('Another blow for the high country', Scoop Independent News, June 2007).

Though high country farmers continue to assert that their interests are the nation's interests, this claim is no longer persuasive. No longer guardians of the nation's heritage, high country farmers are being dislodged from their position as national subject and keeper of a national morality; they are being replaced by the urban environmentalist. 


\section{Conclusion}

Tenure review, it seems clear, will lead to fundamental changes in the high country, in terms of land use, landscape and social system. Some possible futures are indicated in areas where reviews have been completed. Central Otago, for instance, is now known for pinot, not merino, and for adventure tourism, and sheep farming and farmers no longer dominate. This is a new high country, increasingly a site, and object, of consumption. Tenure review is also fundamentally challenging farmer subjectivity. Some have embraced the change, constituting themselves as businessmen, while others hold on to the ideal of stewardship. The sense of loss and anger among farmers evoked by the loss of the high country, the loss of their place as guardians of the nation and their inability to control the outcomes of tenure review can be understood as a version of what Hage (1998:218ff.) calls the 'discourse of Anglo decline'. As Park et al. (2002:527) write of farmers in Northland, '[p]akeha [European] pastoral farmers, key protagonists in a white managerial fantasy, are experiencing themselves as no longer in control of, or as central to, national life as they were'.

These rural transformations also signify a shift in the place of ruralism in the imagining of New Zealand. The land of the high country remains an important feature of the national imaginary, but it is now imagined as a landscape to be viewed or a space of leisure; pastoral farming and pastoral farmers are no longer automatically synonymous with the high country.

\section{Bibliography}

Akers, A. 2004, 'Valley farmers': place attachment and challenges to high country identity from the tenure review process, Unpublished dissertation, Anthropology Program, University of Canterbury, Christchurch.

Altman, I. and Low, S. M. (eds) 1992, Place Attachment, Plenum Press, New York.

Bell, C. 1996, Inventing New Zealand: Everyday myths of pakeha identity, Penguin Books, Auckland.

Bourdieu, P. 1998, Practical Reason: On the theory of action, Stanford University Press, Stanford.

Bremer, R. and Brooking, T. 1993, 'Federated Farmers and the State', in B. Roper and C. Rudd (eds), State and Economy in New Zealand, Oxford University Press, Auckland.

Brower, A. L. 2006, Interest Groups, Vested Interests and the Myth of Apolitical Administration: The politics of land tenure reform on the South Island of New Zealand, Fulbright New Zealand.

Ching, B. and Creed, G. W. (eds) 1997, Knowing Your Place: Rural identity and cultural hierarchy, Routledge, New York. 
Clayton, W. G. 1982, Crown Pastoral Leases and Leases in Perpetuity: Report of the committee of inquiry, Government Printer, Wellington.

Cohen, A. P. 1985, The Symbolic Construction of Community, E. Horwood, Tavistock Publications, Chichester, London and New York.

Cushen, J. 1997, Images of the interior: landscape perceptions of the South Island high country, Master of Arts thesis, University of Otago, Dunedin, New Zealand.

Dominy, M. 1992, 'Knowing this place I learn to know myself': toponymy and topographic representation on New Zealand sheep stations, Paper presented to the 91st annual meeting of the American Anthropological Association, San Francisco.

Dominy, M. 1993, "Lives were always, here": the inhabited landscape of the New Zealand high country', Anthropological Forum, vol. 6, pp. 567-86.

Dominy, M. 2001, Calling the Station Home: Place and identity in New Zealand's high country, Rowman and Littlefield Publishers, Lanham.

Feld, S. and Basso, K. (eds) 1996, Senses of Place, School of American Research Press, Santa Fe, NM, distributed by University of Washington Press, Seattle.

Gardner, W. J. 1981, 'A colonial economy', in W. H. Oliver and B. R. Williams (eds), The Oxford History of New Zealand, Oxford University Press, Wellington.

Gouin, D.-M., Jean, N. et al. 1994, New Zealand Agricultural Policy Reform and Impacts on the Farm Sector, Agribusiness and Economics Research Unit, Lincoln University, Lincoln.

Gray, J. 2000, At Home in the Hills: Sense of place in the Scottish Borders, Berghahn Books, New York.

Gray, J. 2003, 'Open spaces and dwelling places: being at home on hill farms in the Scottish Borders', in S. Low and D. Lawrence-Zúñiga (eds), The Anthropology of Space and Place: Locating culture, Blackwell, Malden, Mass.

Hage, G. 1998, White Nation: Fantasies of white supremacy in a multicultural society, Pluto Press, Sydney, and Comerford and Miller, West Wickham.

Hirsch, E. and O'Hanlon, M. (eds) 1995, The Anthropology of Landscape: Perspectives on place and space, Clarendon Press, Oxford.

Inda, J. X. and Rosaldo, R. 2002, The Anthropology of Globalization: A reader, Blackwell Publishing, Malden, Mass.

Johnsen, S. 2003, 'Contingency revealed: New Zealand farmers' experiences of agricultural restructuring', Sociologia Ruralis, vol. 43, no. 2, pp. 128-53. 
Jutel, T. 2004, “"Lord of the rings": landscape, transformation and the geography of the virtual', in C. Bell and S. Matthewson (eds), Cultural Studies in Aotearoa/New Zealand: Identity, space and place, Oxford University Press, Melbourne.

King, M. 1999, Being Pakeha Now: Reflections and recollections of a white native, Penguin, Auckland.

Low, S. 1992, 'Symbolic ties that bind: place attachment in the plaza', in I. Altman and S. M. Low (eds), Place Attachment, Plenum Press, New York and London.

Low, S. M. and Lawrence-Zúñiga, D. (eds) 2003, The Anthropology of Space and Place: Locating culture, Blackwell, Malden, Mass.

McAloon, J. 2002, No Idle Rich: The wealthy in Canterbury and Otago 1840-1914, University of Otago Press, Dunedin.

McLauchlan, G. 1981, The Farming of New Zealand, Australia and New Zealand Book Company, Auckland and Sydney.

McNay, L. 2000, Gender and Agency: Reconfiguring the subject in feminist and social theory, Polity Press, Cambridge.

Morris, C. 2002, 'Station wives in New Zealand: narrating continuity in the high country', Anthropology, University of Auckland, Auckland.

Morris, C. and Akers, A. 2004, 'Valley farmers': land tenure review and subjectivity in the New Zealand high country, Paper presented at the ASAANZ Conference, Auckland.

Park, J., Scott, K., Cocklin, C. and Davis, P. 2002, 'The moral life of trees: pastoral farming and production forestry in northern New Zealand', Journal of Anthropological Research, vol. 58, pp. 521-44.

Sandrey, R. and Reynolds, R. (eds) 1990, Farming Without Subsidies: New Zealand's recent experience, MAF \& GP Books, Wellington.

Schama, S. 1995, Landscape and Memory, A. A. Knopf, New York, distributed by Random House.

Statistics New Zealand 2002, Agriculture Statistics 2002, viewed 7 August 2007, $<$ http://www.stats.govt.nz/analytical-reports/agriculture-statistics-2002/ the-agricultural-industry.htm $>$

Statistics New Zealand 2008, Defining Urban and Rural New Zealand, $<$ http://www.stats.govt.nz/urban-rural-profiles/defining-urban-rural-nz/default.htm>

Sturm, T. (ed.) 1998, The Oxford History of New Zealand Literature, Oxford University Press, Oxford. 
Wevers, L. 1980, 'Pioneer into feminist: Jane Mander's heroines', in P. Bunkle and B. Hughes (eds), Women in New Zealand Society, George Allen and Unwin, Auckland.

White, M. 2006, 'High country hijack', North and South, November 2006, Auckland.

Williams, R. 1973, The Country and the City, Chatto and Windus, London.

\section{Endnotes}

1 The Waitangi Tribunal was established under the Treaty of Waitangi Act 1975 as a forum for hearing Maori grievances in relation to violations of the Treaty of Waitangi. In 1986, Ngai Tahu, the dominant South Island tribe, lodged a claim. As partial remedy, they sought ownership of high country pastoral leases. High country farmers, arguing that pastoral leases should not constitute part of any remedy, asked anthropologist Michele Dominy, who was working in the area the time, to make a submission on their behalf to the tribunal about their economic, cultural, spiritual and historical links to the land. In their submissions, they drew parallels between their attachment and Maori attachment to land: 'Kevin O'Connor, Professor of Range Management at Lincoln College, has called this affinity [with the land] "landship" and compares it with turangawaewae, in Maoridom' (Dominy 1990:14). They also asserted that they were the indigenous people of the high country: 'A committee member in writing to me said that in their evidence high country people would stress the historical importance of the land to them and "how we feel as though we are the indigenous people of the high country"' (Dominy 1990:14). Indigenous status and a strong spiritual attachment are central to Maori claims of attachment to place and to their claims before the Waitangi Tribunal. In this context, farmers drew on parallel discourses to assert their own claims.

2 Fish and Game represents hunting and fishing interests and has 'a statutory mandate to manage New Zealand's fresh water sportsfish fisheries and gamebird hunting' $(<$ http://www.fishandgame.org.nz $>$ ).

3 Iwi are Maori tribes.

4 Settlements with a population of 1000 people or more are classified as urban for census purposes (Statistics New Zealand 2008).

5 Note that the indigenous people referred to here are high country farmers, not Maori. 